\title{
LIBERDADE SEXUAL E DE GÊNERO NA REDE DE EDUCAÇÃO DO ACRE: OBSERVANDO O CONTEXTO LOCAL
}

\author{
Paulo Victor Poncio de Oliveira ${ }^{(*)}$ \\ Lúcia de Fátima Melo ${ }^{(* *)}$
}

\section{INTRODUÇÃO}

Quando se fala de liberdade de gênero ${ }^{1}$ e diversidade sexual ${ }^{2}$ no contexto educacional, o que se vê, tanto nacional quanto regionalmente, é um cenário de legislações repletas de contrassensos e contradições. Enquanto alguns especificam orientações sobre a temática nos campos social e educacional, outros suprimem termos que poderiam incentivar o diálogo e a equidade. No geral, a questão repercute, pois lida com históricas tradições normativas que baseiam as sociedades há séculos, todavia o espaço de debates cresce a cada nova manifestação social e documento publicado. No Estado do Acre, teoricamente as coisas não são diferentes, pois a produção de políticas públicas educacionais que lidam com a liberdade de gênero, cresce ao passo em que grupos conservadores oprimem as estruturas políticas, resistindo às mudanças.

Uma proposta eficiente de troca de ideias e experiências deve transformar a escola em um ambiente de equilibrio social e ético na luta por igualdade e paz, que caminha junto a questões importantes relativas à saúde, como a discussão sobre iniciação sexual, pornografia, violência e prostituição. Logo se vê que o debate acerca de liberdade de gênero e diversidade sexual é amplo e extrapola os conceitos de orientação e sexualidade, pois reúne uma vasta gama de possibilidades e oportunidades de diálogo sobre cidadania e ética, papel social histórico da educação. Não sendo

\footnotetext{
${ }^{(*)}$ Mestre em Educação pela Universidade Federal do Acre (2017) e tecnólogo em Gestão Pública pela Universidade Norte do Paraná (2016). Atualmente integra o quadro de Técnicos Administrativos em Educação da Universidade Federal do Acre, atuando nas áreas de assessoramento das atividades de ensino da Pró-Reitoria de Graduação.

${ }^{(* *)}$ Professora do Programa de Pós-graduação em Educação da Universidade Federal do Acre (PPGE/UFAC). Possui graduação em Pedagogia pela UFAC (1992); especialização em Currículo e Avaliação Educacional também pela UFAC (1996); mestrado em Educação pela Universidade Federal do Rio de Janeiro (UFRJ)(2002) e doutorado em Educação: conhecimento e inclusão social pela Universidade Federal de Minas Gerais (UFMG) na linha de pesquisa: Políticas Públicas Educacionais: concepção, implementação e avaliação (2010).

${ }^{1}$ Conceito moderno que se entrelaça com a concepção de igualdade de gênero. Segundo o Boletim n .. 149, do Instituto Brasileiro de Ciências Criminais (IBCC), publicado em 2005 e disponível através do link <https://www.ibccrim.org.br/ boletim_artigo/2950-Diferencas-de-genero-liberdade-e-igualdade>, para assegurar a liberdade material das pessoas é indispensável preservar e garantir a igualdade entre elas, especialmente quanto às diferenças de gênero. Acesso em: 14 abr. 2019.

${ }^{2}$ Conceito usado para identificar de maneira inclusiva, toda a diversidade de sexos, orientações sexuais e identidades de gênero existentes nas sociedades.
} 
possível o consenso, resta saber se o discurso dos movimentos tradicionais abafará a voz de toda a população LGBTQIA $^{3}$ acriana.

Assim, este trabalho discute algumas questões sobre liberdade de gênero e diversidade sexual na escola acriana, visto que a intenção é focar o contexto local de maneira mais detalhada e as políticas voltadas para liberdade de gênero e diversidade sexual na Rede Estadual de Educação Básica do Acre. Para tanto, utilizou-se a empiria como forma de revelar as similaridades e especificidades dessas questões, tendo como parâmetro as visões/opiniões de diferentes sujeitos envolvidos diretamente com a problemática.

\section{O CONTEXTO INSTITUCIONAL: A VISÃO DA COORDENAÇÃO DE EDUCAÇÃO PARA OS DIREITOS HUMANOS, CIDADANIA E DIVERSIDADE (CEDHCD) DA SECRETARIA DE ESTADO DE EDUCAÇÃO E ESPORTE (SEE) DOACRE}

De acordo com a coordenadora da pasta, no contexto de uma visita à gestão da CEDHCD da SEE, a SEE é uma instituição que passou a abordar questões de gênero e diversidade há pouco tempo, em virtude de reestruturações que vêm sendo feitas pelos últimos governos estaduais. Nesse contexto, vê-se a criação, dentro da estrutura organizacional da SEE, da Diretoria de Inovação, responsável por promover ações ligadas à tecnologia, modernização e diversidade. A partir disso, em pouco tempo ficou evidente a necessidade de um setor especificamente vinculado às questões de raça e costumes - e nesse cenário, é criada a CEDHCD, no ano de 2015. Não obstante a isso, a coordenadora enfatizou também a importância do surgimento, na mesma época, da Divisão de Promoção da Cidadania LGBT da Secretaria Estadual de Justiça e Direitos Humanos (SEJDH), que seria responsável pelo enfrentamento à discriminação, quando do acompanhamento das atividades e metas do Conselho Estadual de Combate à Discriminação (CECD).

Quando perguntada se durante sua formação inicial estudou sobre esse tema em sala, a coordenadora afirmou que não, apesar de declarar que foi orientada após a sua formação, quando de eventuais cursos de capacitação voltados para professores e gestores da Rede. No que diz respeito às expectativas da sociedade perante o homem e a mulher, considera, ainda, que existem diferenças grandes, no sentido de existir um imaginário social que diminui a mulher a um papel doméstico de

\footnotetext{
3 Recente atualização norte-americana da sigla LGBT (Lésbicas, Gays, Bissexuais, Travestis, Transexuais e Transgêneros), que agora adiciona os grupos Q - queer (pessoas de ambos os gêneros que possuem uma variedade de orientações, preferências e hábitos sexuais neutros e eventualmente simultâneos e/ou misturados), I - intersex (pessoas em que seu porte físico não é expresso por características sexuais unicamente masculinas ou femininas) e a vogal A que se refere a dois grupos distintos, sendo assexual (pessoa assexuada ou que não possui orientação sexual definida) e ally (pessoas que não se identificam com o grupo LGBTQIA, mas o respeita e as segura que seus direitos sejam cumpridos). Mais informações podem ser acessadas através do link <http://lgbtqia.ucdavis.edu/>.
} 
subserviência ao homem, ao passo em que se espera uma liderança masculina natural. Segundo a gestora, o debate que se apresenta em relação aos novos papéis sociais que surgem na pósmodernidade abre um leque de possibilidades de diálogo nunca antes visto.

No que se refere a ter presenciado algum tipo de discriminação quanto à orientação sexual no ambiente escolar, afirma que várias vezes presenciou, inclusive necessitando intervir em situações críticas, de forma que aproveitou tais momentos para orientar as partes, no sentido de aprenderem sobre respeito e tolerância. Destarte, acha que é fundamental propor esse diálogo dentro da escola, de maneira a aprofundar o tema, buscando discutir possíveis soluções com os alunos, ao tempo em que critica a reflexão de grupos que fazem resistência à ampliação sem fronteiras desse debate no contexto educacional.

Sob o viés da discussão sobre como esses temas poderiam ser tratados na sala de aula, a gestora defende a metodologia interdisciplinar, apesar de também afirmar que as instituições educacionais brasileiras e acrianas não têm todas as condições necessárias, estruturais e/ou pedagógicas, para tratar de assuntos tão complexos da forma ideal. Para ela, faltam investimentos governamentais em Educação Básica, ao passo em que não se vê um número expressivo de congressistas federais dispostos a assumir a causa LGBTQIA.

No caso específico da Rede de Educação do Acre, no que tange ao trabalho desenvolvido pela CEDHCD, a gestora ainda abordou as resistências que sente por parte das comunidades de muitas escolas, quando da visita e promoção de palestras ou rodas de conversas - fica evidente, nesse momento, seu ceticismo em relação à solução das demandas que surgem. Para além disso, a SEE, por intermédio da CEDHCD, consegue apoiar as escolas de forma pontual, sendo necessário algum tempo e desgaste para que as atividades planejadas possam ser, de fato, realizadas com a eficiência que se espera. Todavia, a coordenadora entrevistada defende a manutenção das poucas ações que já se firmaram, além do fortalecimento da rede de contatos criada durante os anos de atividade da Coordenação.

Por fim, ficou evidenciada a preocupação da SEE em relação ao crescimento no número de grupos conservadores extremistas, ao passo em que se defende, a todo custo, a possibilidade de diálogo aberto e claro contínuo, sobre liberdade de gênero e diversidade sexual no contexto das políticas públicas educacionais. 


\section{O CONTEXTO ESCOLAR: A VISÃO DOS (AS) COORDENADORES(AS) DAS ESCOLAS DE ENSINO MÉdIO DA REDE PÚBLICA DE EDUCAÇÃO BÁSICA DO ACRE}

Ainda buscando compreender as decorrências pedagógicas do debate sobre sexo, sexualidade e gênero, esta pesquisa se apresentou procurando, dentre outros fatores, identificar como as políticas públicas educacionais em curso na Rede Estadual de Educação Básica do Acre trabalham com as questões relacionadas à liberdade de gênero e diversidade sexual.

Para tanto, foram visitadas nove escolas da cidade de Rio Branco, que representaram todas as Regionais definidas pela Rede ${ }^{4}$, ao passo em que todas as equipes de coordenadores pedagógicos foram convidados a responder questionários. Os resultados obtidos junto às escolas visitadas foram analisados de forma a ressaltar as especificidades de cada uma delas. Uma questão que já se pode afirmar com apoio das investigações, é que a Rede Pública de Educação do Acre carece de uma estrutura sistematizada de formação em gênero e diversidade em interação às escolas. Seguem abaixo os dados mais expressivos encontrados por meio dos questionários, na qual se procurou aproximar a fala dos sujeitos investigados com as discussões explicitadas no referencial teórico desta dissertação.

\section{QUANTO AO PERFIL SOCIODEMOGRÁFICO}

Dentre os atores participantes, foram entrevistados dez coordenadores(as) pedagógicos(as) e/ou de ensino nas nove escolas visitadas, tendo em vista que em uma única escola, dois coordenadores aceitaram participar da pesquisa. Desse universo, oito foram coordenadores(as) pedagógicos(as), encarregados(as) de todo o trabalho pedagógico, incluindo o planejamento pedagógico, vertical e horizontal das séries e turnos pelos quais estiver responsável, auxiliando os professores na elaboração de seus planos de curso e respectivos planos de aula, e dois foram coordenadores de ensino das referidas escolas de Ensino Médio, responsáveis pelas ações de planejamento voltadas para o desenvolvimento do currículo e a melhoria da qualidade de ensino.

\footnotetext{
${ }^{4}$ No que tange às nove regionais elencadas, tal escolha pautou-se na classificação que é adotada pela SEE do Acre, que subdivide a Rede Estadual de Educação do Acre em tais regionais territoriais, para melhor observar e acompanhar as gestões das escolas.
} 


\section{Gráfico 1. Percentual de coordenadores entrevistados quanto a suas funções na escola}

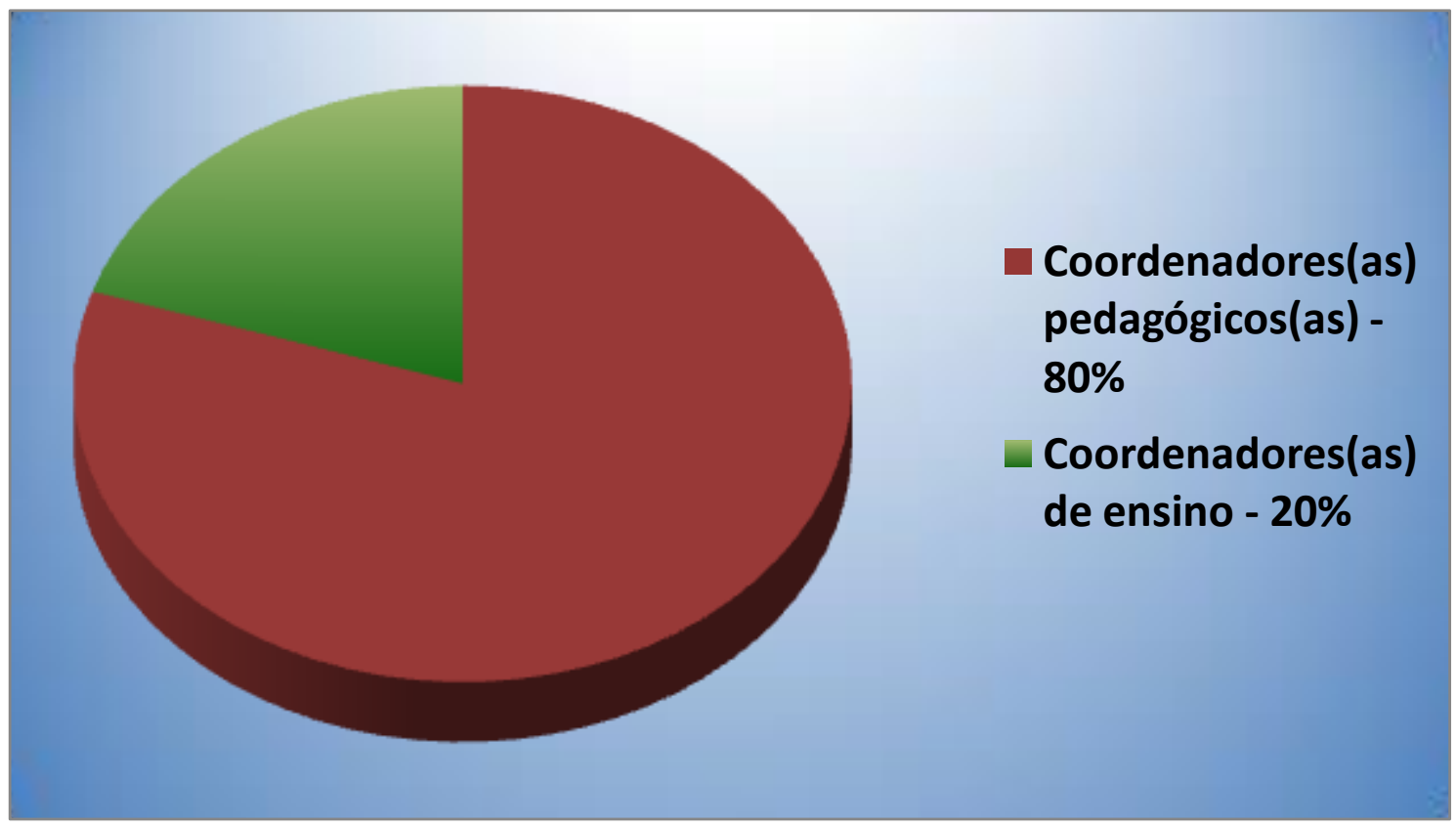

Fonte: Elaborado pelos autores, com dados coletados através de pesquisa empírica nas escolas.

No que diz respeito ao sexo, dentre os dez coordenadores(as), seis declararam ser do sexo feminino, enquanto somente quatro, do sexo masculino. Temos aqui um número que reflete a histórica feminização do magistério brasileiro - situação educacional bastante discutida, quando da confrontação entre os índices de mulheres e homens atuando como professores da educação básica. Em relação à trajetória dessa feminização, no que tange aos desafios que se apresentam para a prática e a identidade coletiva docente, pondera Vianna (2003):

A reflexão advinda da sociologia do trabalho, por meio das metáforas do "teto de vidro" e da "escada rolante invisível”, propagadas por Williams (1995) para simbolizar as barreiras que impedem a promoção de muitas mulheres em suas carreiras e os incentivos invisíveis que impulsionam a promoção de homens em ocupações femininas, como é o caso do magistério, ilustra bem o desafio a ser enfrentado quando tratamos dos significados de gênero constituintes do processo de feminização da docência. Assim, a meu ver, a reflexão sobre a identidade docente, integrada à perspectiva de gênero, pode levar em conta a mediação entre esses diferentes registros e buscar compreensão das tensões que necessariamente caracterizam a feminização do magistério. (2013, p. 21). 


\section{Gráfico 2. Percentual de coordenadores entrevistados quanto a seus sexos}

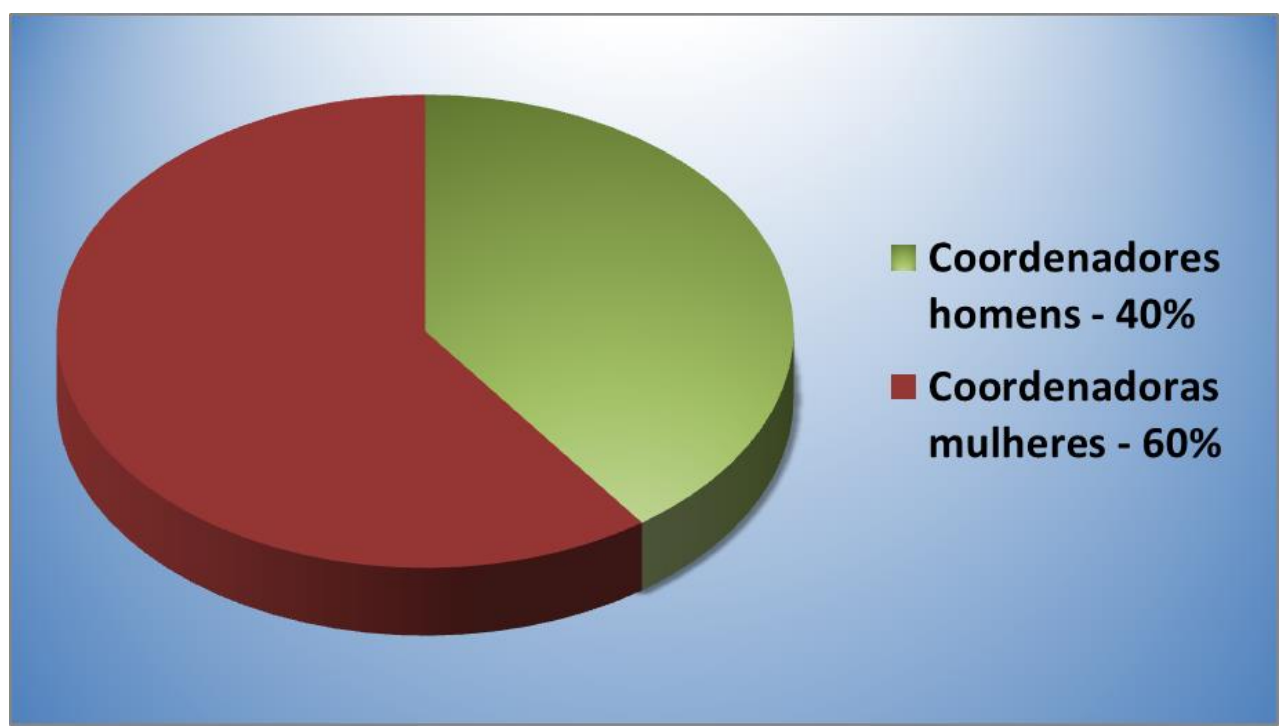

Fonte: Elaborado pelos autores, com dados coletados através de pesquisa empírica nas escolas.

No que tange à idade, 5 (cinco) coordenadores(as) afirmaram possuir entre 31 e 40 anos, 3 (três) afirmaram possuir entre 41 e 50 anos e 2 (duas) coordenadoras, entre 51 e 60 anos. Apresentase aqui um dado que formaliza uma média aritmética de 43 (quarenta e três) anos de idade dentre todos os 10 coordenadores entrevistados.

\section{Gráfico 3. Proporção de coordenadores entrevistados quanto a suas idades}

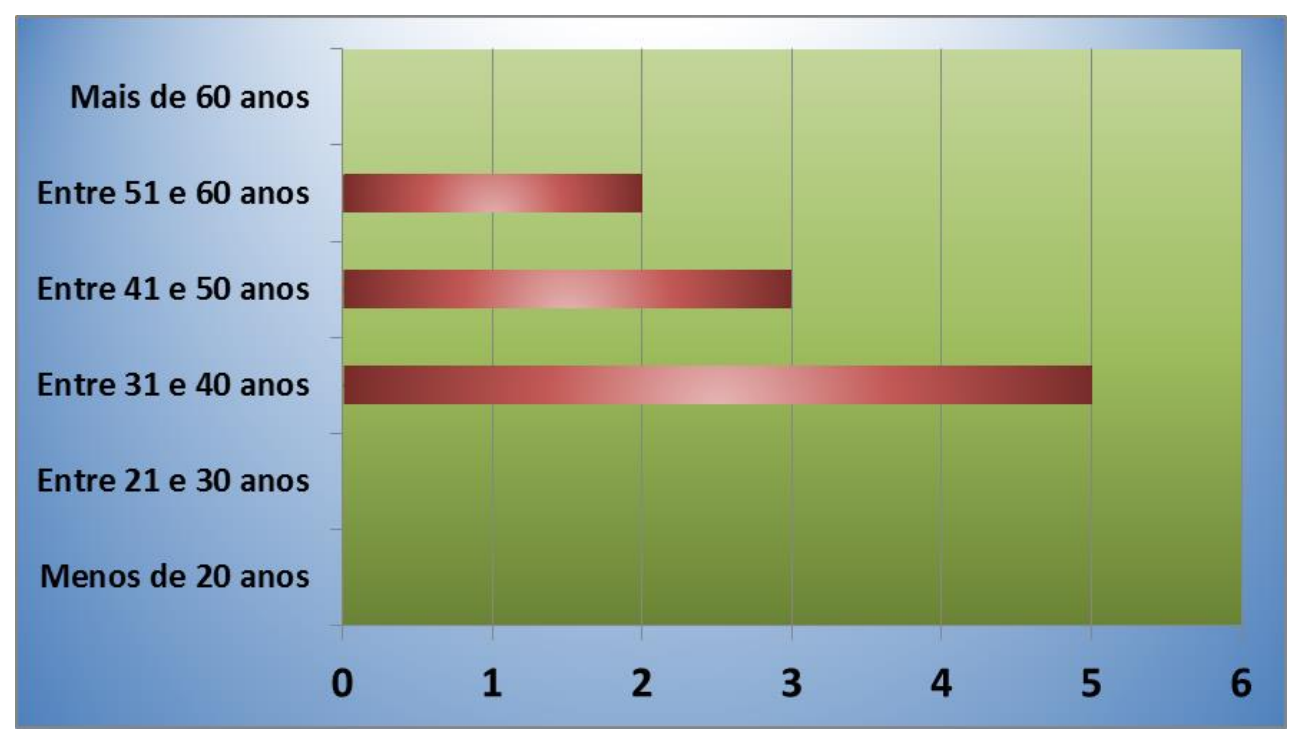

Fonte: Elaborado pelos autores, com dados coletados através de pesquisa empírica nas escolas .

Já no que se refere à renda familiar declarada, 9 (nove) dentre os 10 coordenadores(as) afirmaram possuir ganhos que ultrapassam 5 salários mínimos (mais de R $\$ 4.770$ ), enquanto apenas uma coordenadora declarou possuir renda familiar mensal com valores entre 2 a 5 salários mínimos $(\mathrm{R} \$ 1.908$ a $\mathrm{R} \$ 4.770)$. 


\section{Gráfico 4. Proporção de coordenadores entrevistados quanto a suas rendas familiares declaradas}

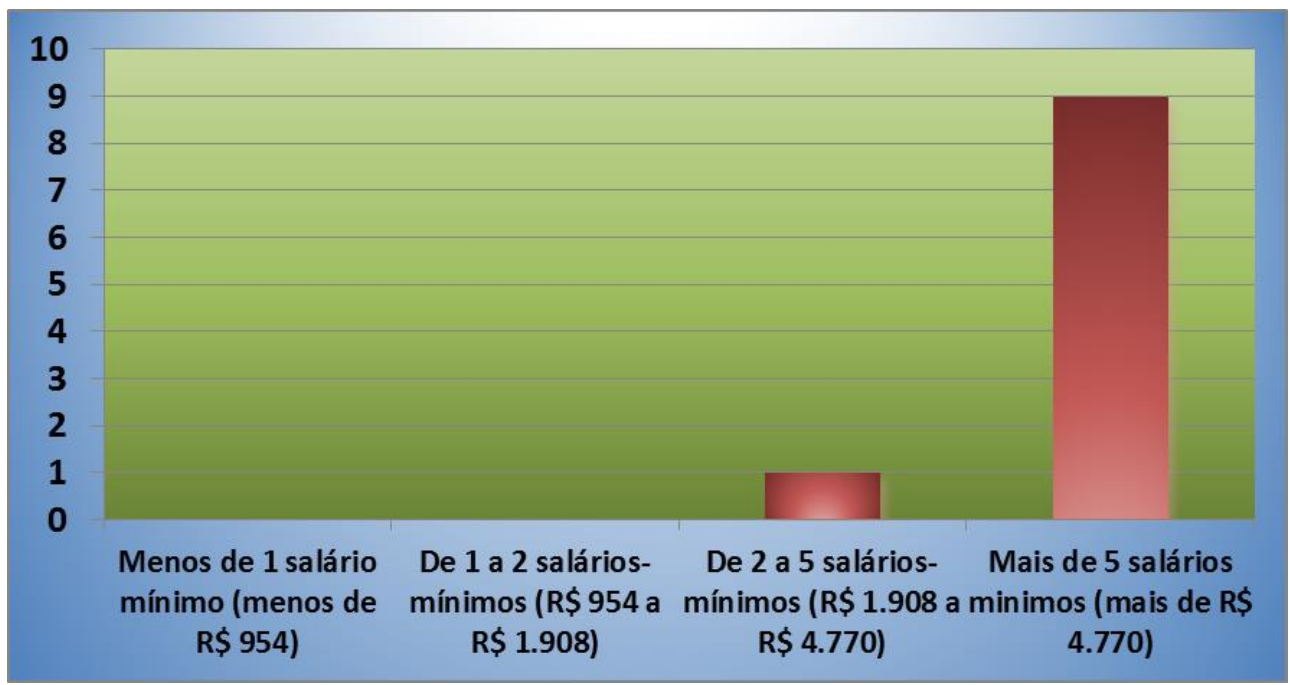

Fonte: Elaborado pelos autores, com dados coletados através de pesquisa empírica nas escolas.

No que tange ao nível de escolaridade, 8 (oito) coordenadores(as) afirmaram possuir Ensino Superior Completo, ao passo em somente 2 (duas) coordenadoras declararam já possuir Curso de Pós-Graduação concluído.

\section{Gráfico 5. Proporção de coordenadores entrevistados quanto a seus níveis de escolaridade}

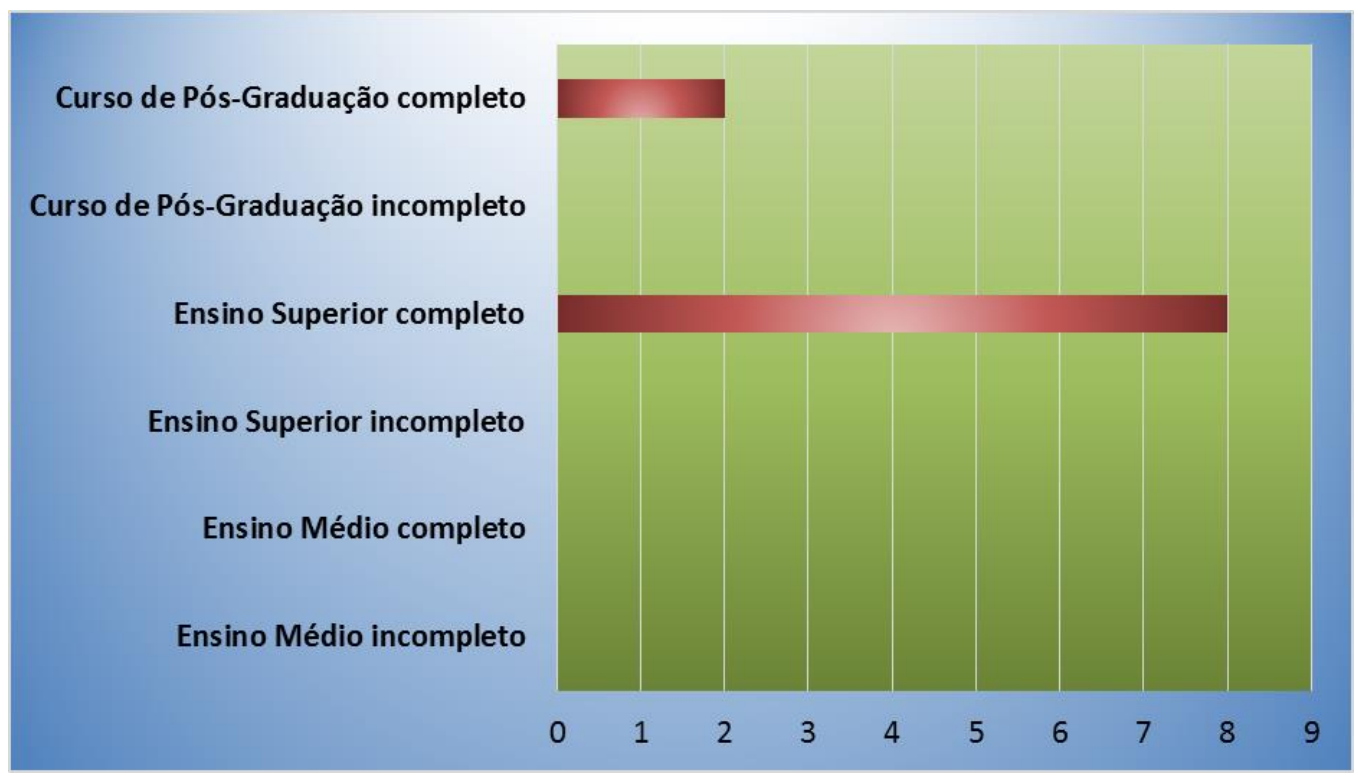

Fonte: Elaborado pelos autores, com dados coletados através de pesquisa empírica nas escolas.

Em relação à religião, quatro coordenadores(as) declararam seguir os dogmas católicos, dois declararam seguir a religião evangélica, ao passo em que um coordenador declarou ser espírita e três afirmaram não seguir nenhuma religião. Tais números, provando que a maioria dos 
coordenadores segue a religião católica, sinalizam para o fato de que a religião influencia a visão que se tem sobre a discussão de gênero e diversidade na escola. Como analisado a partir da pesquisa teórica, grupos ligados a algumas religiões têm maior probabilidade de resistência ao debate sobre costumes nas escolas. De acordo com Lima (2011):

$\mathrm{Na}$ cultura ocidental, a heterossexualidade como norma compulsória a qual todos/as devem se adequar - e que vê a homossexualidade como perversão - tem suas raízes no imaginário judaico-cristão. [...] Assim, o Estado laico é uma conquista moderna que não pode advogar e defender valores religiosos, mas deve defender os direitos de todos os cidadãos, inclusive dos homossexuais, sejam estes ateus ou religiosos. (p. 177).

\section{Gráfico 6. Proporção de coordenadores entrevistados quanto a suas religiões}

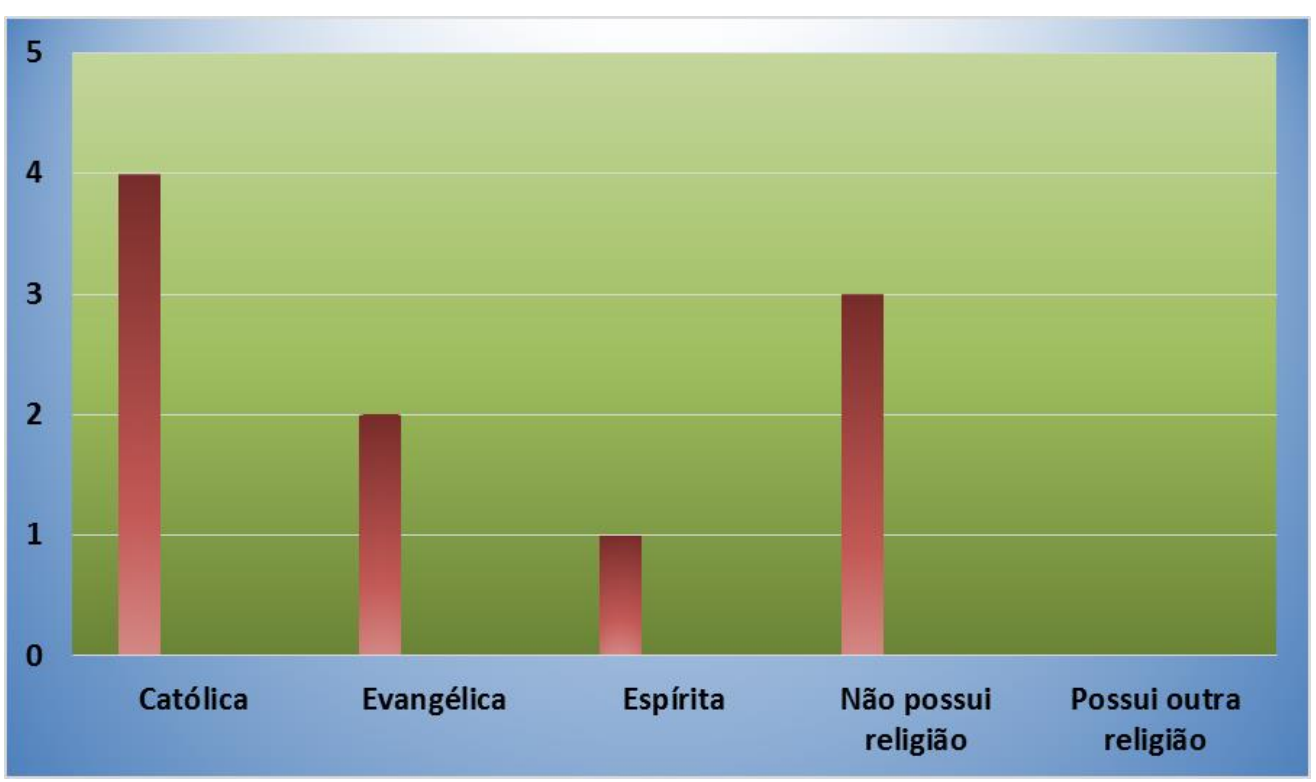

Fonte: Elaborado pelos autores, com dados coletados através de pesquisa empírica nas escolas .

Já no que tange à experiência dos(as) coordenadores(as) à frente de coordenações pedagógicas e/ou de ensino da Rede Estadual de Educação, a pesquisa concluiu a primeira parte do questionário semiaberto perguntando aos entrevistados há quanto tempo atuam como coordenadores da Rede. Como resposta, 2 coordenadores responderam que atuam há menos de 1 (um) ano, 5 (cinco) responderam entre 2 (dois) e 5 (cinco) anos, 2 entre 6 (seis) e 10 (dez) anos e 1 declarou já ter experiência de mais de 11 anos há frente de coordenações, o que resulta aqui, em uma média de 4,75 (quatro vírgula setenta e cinco) anos.

Em relação à influência do saber funcional e prático na prática docente, no contexto dos saberes experienciais que acontecem por intermédio da interação do coordenador com os demais professores e alunos, Lopes esclarece: 
[...] No entanto, não há como negar a funcionalidade do saber da experiência do professor no desenvolvimento cotidiano das atividades pedagógicas. Sendo funções básicas do professor: ensinar, dialogar, mediar, intervir, tomar decisões, especular, refletir, reconsiderar, o saber experiencial adquire uma importância inequívoca para o professor que vai construindo no dia-a-dia a sua práxis pedagógica. É nessa perspectiva que o mesmo autor caracteriza o saber da experiência como um saber prático, pois "a sua utilização depende de sua adequação às funções, problemas e situações peculiares ao trabalho" (LOPES, 2009, p. 6).

\section{Gráfico 7. Proporção de coordenadores entrevistados quanto a suas experiências em coordenações de escolas da Rede}

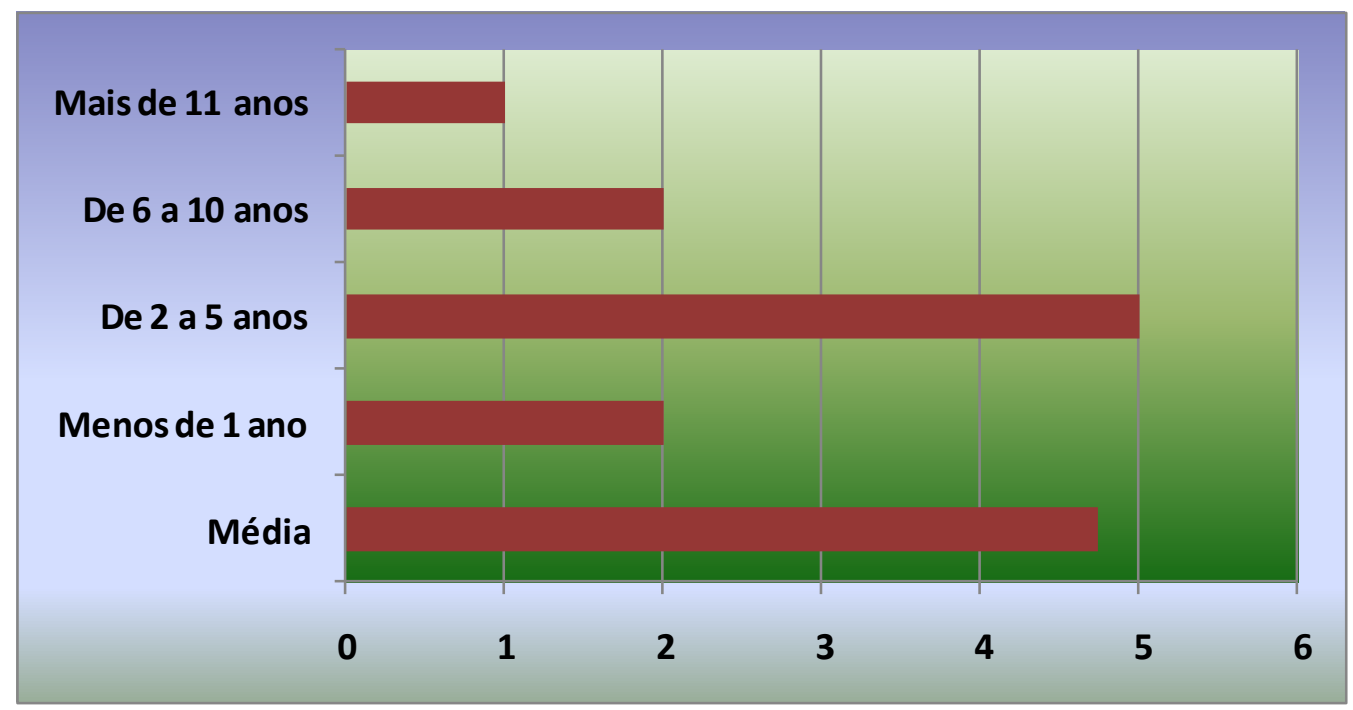

Fonte: Elaborado pelos autores, com dados coletados através de pesquisa empírica nas escolas .

\section{QUANTO AOS DADOS RELATIVOS À LIBERDADE DE GÊNERO, DIVERSIDADE SEXUAL E POLÍTICAS PÚBLICAS EDUCACIONAIS}

Quando perguntados se durante a formação inicial estudaram sobre esses temas em alguma disciplina na sala de aula ou mesmo se precisaram fazer alguma atividade extracurricular, todos os coordenadores responderam que não, de forma unânime. Tal situação evidencia a negligência que as instituições acadêmicas também assumem, como parcela de culpa no contexto da falta de políticas públicas educacionais referentes a gênero e diversidade.

Não obstante o fato de a academia possuir currículos desatualizados e modorrentos, se almejarmos investir na formação e, por conseguinte na prática crítica e reflexiva, é fundamental refletir sobre a formação inicial, assim como também sobre a continuada, de forma a sistematizar ações que incentivem a pesquisa, mirando o desenvolvimento de habilidades e competências que ajudem os docentes para o desenvolvimento de ações críticas e reflexivas. 
Em relação à sobre como lidar com questões relativas à sexualidade, 3 (três) coordenadores declararam já terem tido momentos de orientação nesse sentido dentro da escola, ao passo em que 7 (sete) afirmaram nunca terem sido orientados.

\section{Gráfico 8. Percentual de coordenadores entrevistados quanto às vezes que já foram orientados} sobre gênero e diversidade na escola

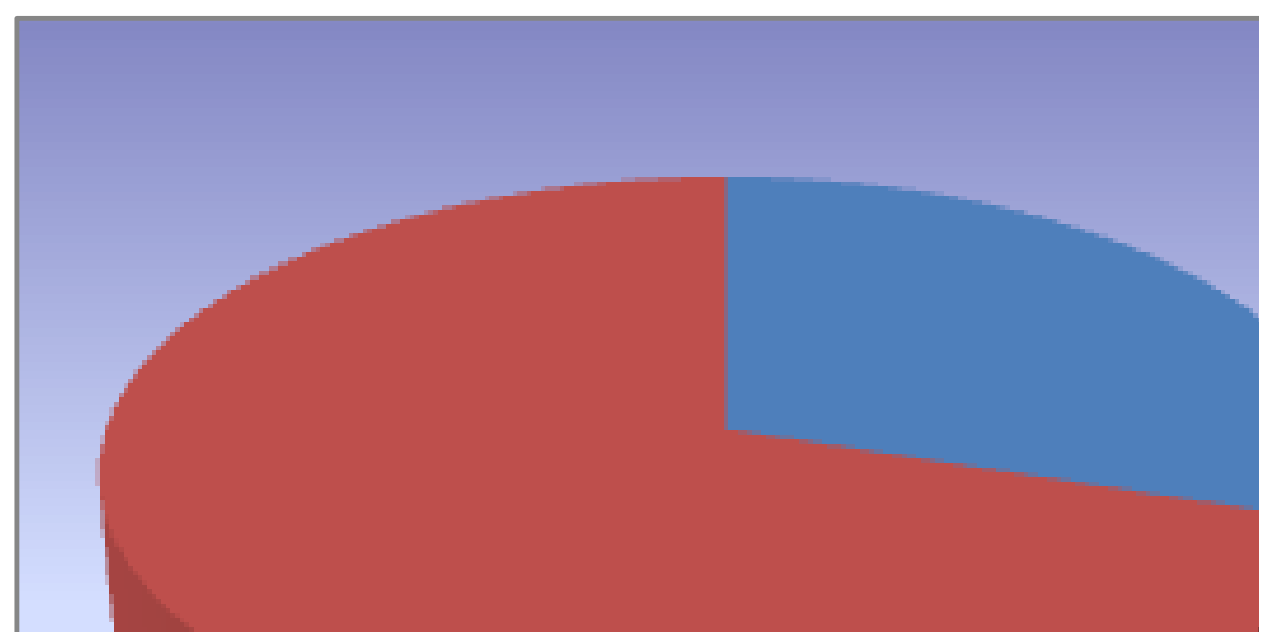

Fonte: Elaborado pelos autores, com dados coletados através de pesquisa empírica nas escolas .

Quando perguntados se já fizeram algum curso de capacitação voltado para gestores e/ou professores, que incluísse a questão da sexualidade, 6 (seis) coordenadores afirmaram que não, enquanto 4 (quatro) declararam que sim, citando brevemente o que de fato viram nessas eventuais capacitações dirigidas a gestores: Encaminhamentos sobre orientação sexual, pedofilia, assédio e abuso sexual.

Em relação ao papel da mulher e do homem perante a sociedade atual, 2 coordenadoras acham que a sociedade possui as mesmas expectativas quanto à profissão e as relações pessoais, 1 coordenadora declarou não saber, enquanto 7 afirmaram achar que a sociedade tem expectativas diferentes para homens e mulheres.

\section{Quadro 1. Características que os coordenadores(as) entrevistados(as) acham que a sociedade espera do homem e da mulher}

\begin{tabular}{|c|c|}
\hline $\begin{array}{c}\text { Características masculinas } \\
\text { Controle da família }\end{array}$ & $\begin{array}{c}\text { Características femininas } \\
\text { Responsabilidades domésticas }\end{array}$ \\
\hline Liderança & Sensibilidade \\
\hline Força & Apoiadora do marido \\
\hline Objetividade & Provedora dos filhos \\
\hline
\end{tabular}

Fonte: Elaborado pelos autores, com dados coletados através de pesquisa empírica nas escolas . 
No que tange às vezes em que lidaram em sala de aula ou no ambiente escolar com questões relacionadas a sexo e/ou orientações sexuais, nove coordenadores declararam já ter passado por situações de conflito enquanto educadores, ao passo em que apenas um afirmou nunca ter lidado com tais questões. Já sobre às vezes em que presenciaram, no ambiente escolar, algum tipo de discriminação quanto à orientação sexual de algum membro da comunidade, novamente nove coordenadores declararam já ter vivenciado tais ocorrências, enquanto um afirmou nunca ter presenciado atos discriminatórios.

Nesse contexto, além do poder público, docentes e gestão escolar têm de estar alerta ao papel que exercem na formação da sociedade. Não raramente é preciso colocar em discussão os próprios preconceitos para, assim, transformar a realidade. Enquanto houver alunos sendo expostos à violência física ou simbólica, todos estão sendo abusados indiretamente.

\section{Gráfico 9. Proporção de coordenadores entrevistados quanto a terem lidado com a temática ou presenciado discriminação na escola}

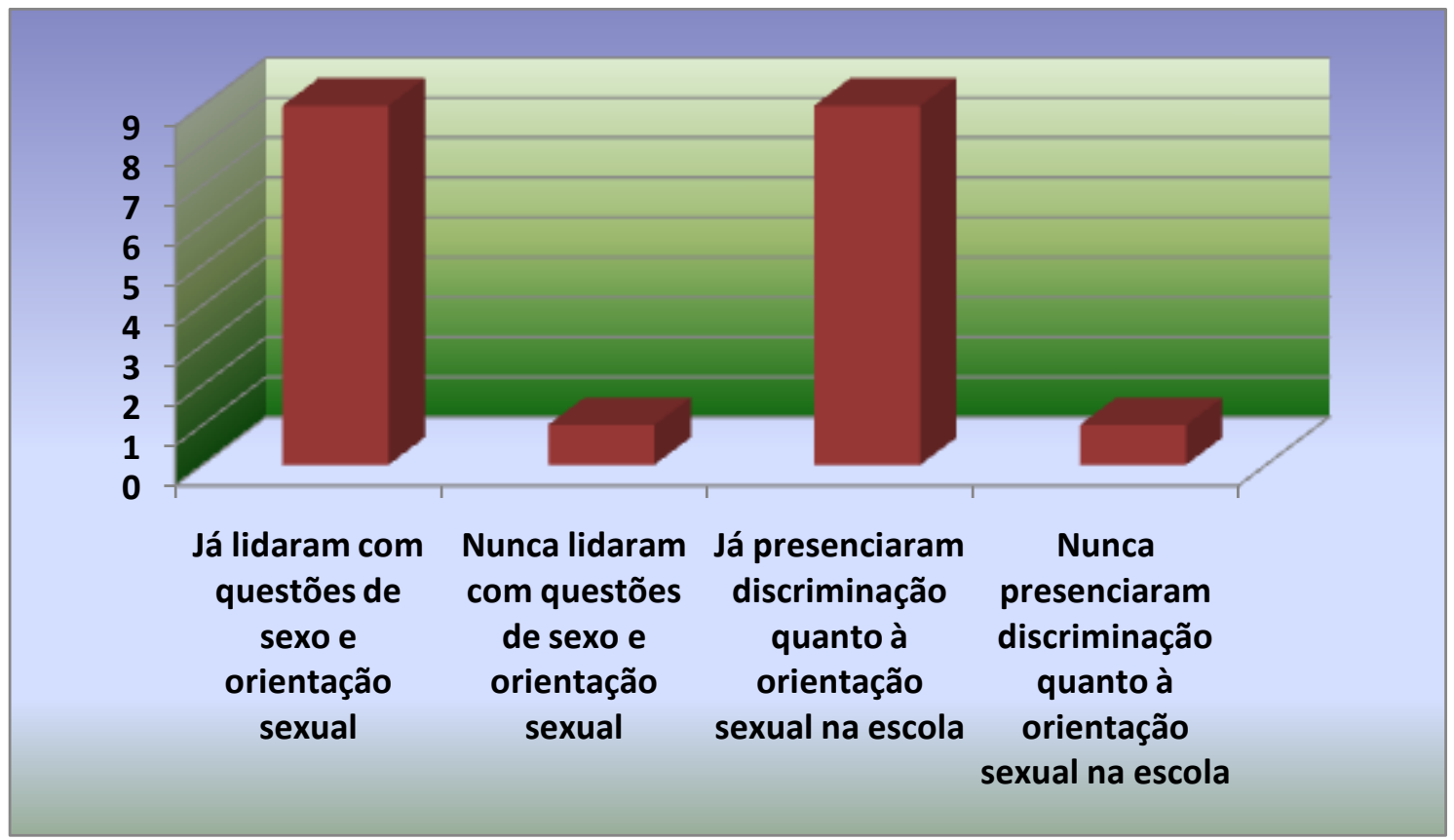

Fonte: Elaborado pelos autores, com dados coletados através de pesquisa empírica nas escolas .

Quando perguntados acerca da origem da homossexualidade, 2 (dois) coordenadores afirmaram que ela é genética, ou seja "já nasce com a pessoa"; 2 (dois) afirmaram que ela é aprendida, ou seja, depende das experiências da vida da pessoa; 1 (um) afirmou que ela é uma escolha, ou seja, a pessoa opta por ser homossexual; ao passo em que 5 (cinco) declararam não ter opinião a respeito. 
Gráfico 10. Percentual de coordenadores entrevistados quanto a suas opiniões sobre a origem da homossexualidade

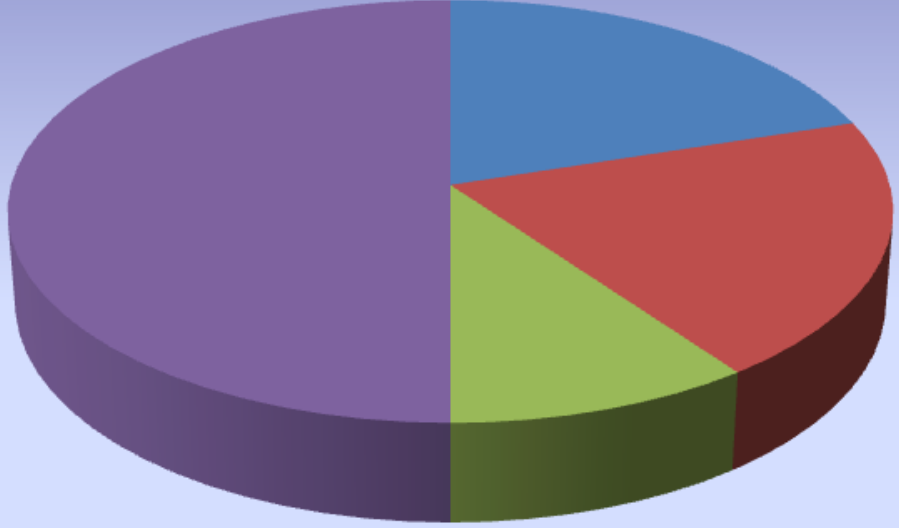

É aprendida - $20 \%$

É genética - $20 \%$

É uma escolha - $10 \%$

Não soube responder $50 \%$

Fonte: Elaborado pelos autores, com dados coletados através de pesquisa empírica nas escolas .

Já sobre o que acham de incluir nas atividades escolares, discussões sobre as questões referentes a sexo, sexualidade e gênero, uma coordenadora considera não ser papel de a escola promover discussões sobre esses temas, pois isto é responsabilidade da família e das campanhas do governo; duas acham que a escola deve informar os alunos, mas não enfatizar muito o assunto para não estimular a iniciação sexual dos alunos; seis consideram que a escola deve sim promover discussões sobre essa temática na escola, pois uma de suas responsabilidade é promover esclarecimentos sobre este assunto; ao passo em que apenas uma coordenadora tergiversou, afirmando que a escola deve se basear apenas na discussão sobre respeito, de forma genérica. Citese aqui a importância do debate específico, de forma a tratar minuciosamente dos problemas sociais que surgem, oriundos de preconceitos e reafirmação de estereótipos. 


\section{Gráfico 11. Proporção de coordenadores entrevistados quanto a suas opiniões sobre o papel da escola na discussão desses temas}

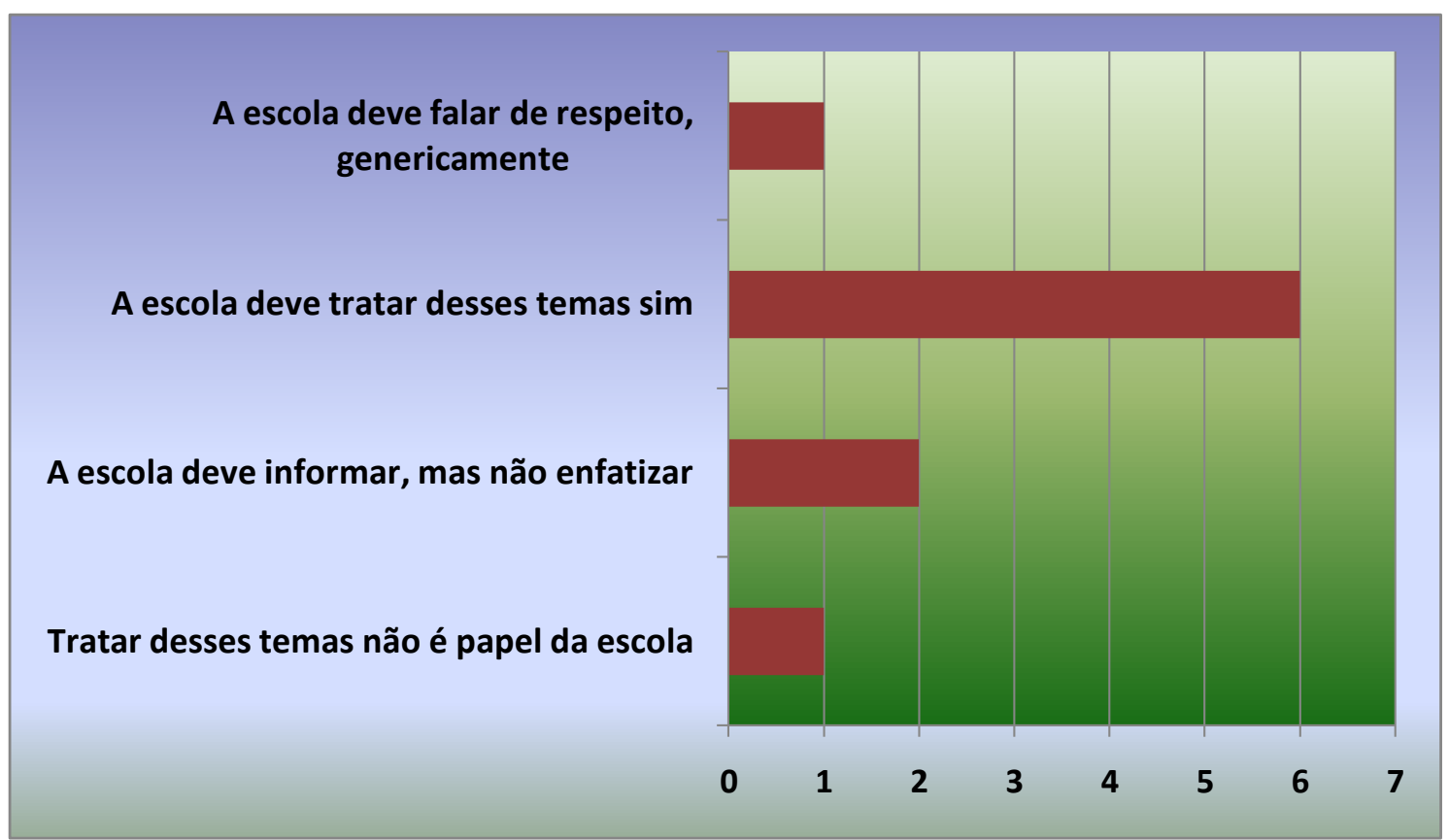

Fonte: Elaborado pelos autores, com dados coletados através de pesquisa empírica nas escolas .

Filtrando o próximo questionamento apenas para aqueles coordenadores que defendem que a escola deve sim tratar desses temas, foi perguntado se consideram que essa temática deve ser tratada na escola como um conteúdo específico ou de maneira interdisciplinar junto às demais disciplinas escolares. Nesse contexto, todos responderam unanimemente, no sentido de considerar a interdisciplinaridade como a melhor forma de tratar das questões relativas à costumes.

Em relação a experiências acrianas de êxito, foi questionado se conhecem algum projeto em andamento que possa servir de modelo para eventuais movimentos paralelos. Sob esse viés, 8 (oito) coordenadores responderam que não conhecem experiência alguma, enquanto 2 (dois) citaram contextos insipientes de orientação promovida pela própria SEE, em relação à conscientização sobre o uso do nome social - de toda forma, ficou evidente que tais orientações não caracterizam projetos exemplares, pois não se deram por promoção de nenhuma escola de Ensino Médio da Rede.

Também foi perguntado aos dez coordenadores(as) participantes desta pesquisa se acham que a educação atualmente tem condições estruturais e didáticas para tratar desse tema. Nesse cenário, temos o primeiro empate entre as opiniões declaradas, visto que cinco consideram que sim, ao passo que cinco acham que a Rede é carente de mecanismos que possam auxiliar os professores nessa discussão, que se torna muito mais desafiadora quando da falta de apoio técnico, estrutural e/ou pedagógico. 


\section{Gráfico 12. Percentual de coordenadores entrevistados quanto a suas opiniões sobre a educação ter ou não condições de tratar desses temas}

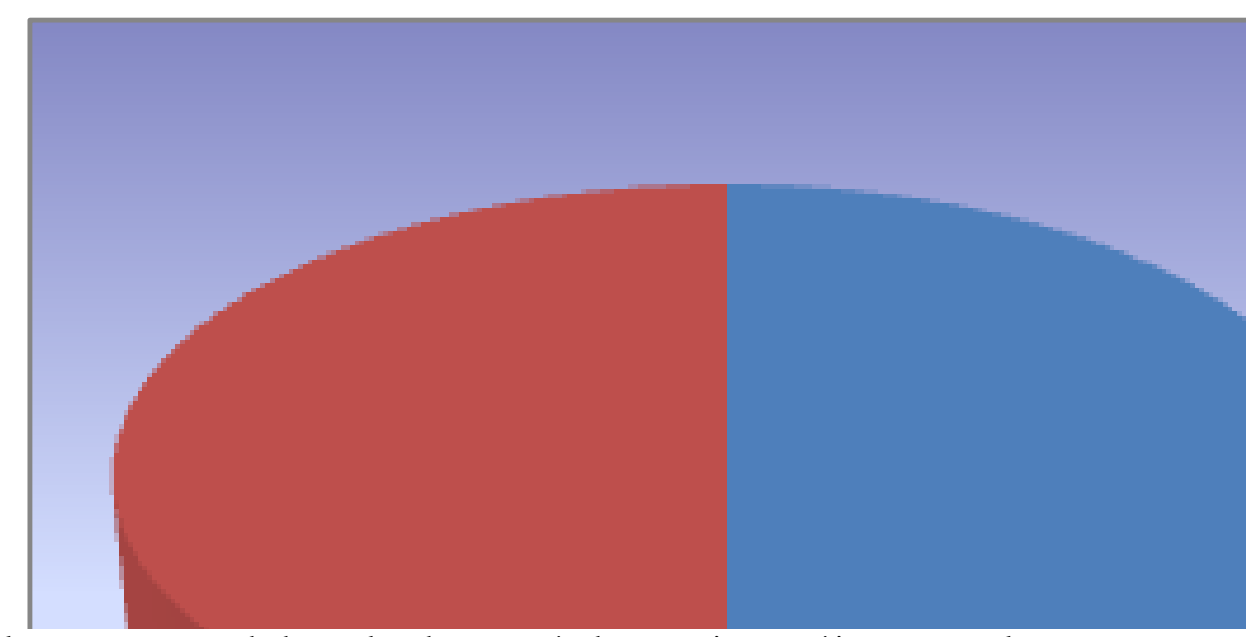

Fonte: Elaborado pelos autores, com dados coletados através de pesquisa empírica nas escolas .

Quando perguntados se acham que existem resistências de grupos da sociedade que não gostariam que esse tema fosse discutido na escola, 9 (nove) coordenadores consideram que sim, enquanto apenas 1 (um) coordenador acredita que não existem resistências. No que tange à quais grupos resistem à inclusão desse debate na escola, foram citadas irmandades religiosas, grupos de docentes conservadores, assim como a própria família, que em alguns casos, não é aberta ao diálogo e acaba por reforçar preconceitos arraigados no imaginário social.

Curiosamente, um dos coordenadores que acreditam haver resistências, abordou que tais conflitos podem estar sendo gerados por causa de próprios grupos LGBTQIA, cuja forma de imposição se dá de maneira grosseira ou desrespeitosa. Indubitavelmente, é importante que a sociedade manifeste uma visão crítica, de fato transformadora, no sentido de compreender as formas de luta dos variados grupos, sem julgar tais contextos sob o ponto de vista individual, tradicionalmente vinculado a um imaginário social conservador.

Já no que se refere a como suas escolas vêm trabalhando o processo de implantação de atividades sobre gênero e diversidade na Rede Estadual, os(as) coordenadores(as) entrevistados(as) abordaram vários aspectos característicos, no sentido de apresentar uma breve visão do que de fato é realizado, apesar dos problemas elencados e das eventuais necessidades estruturais e/ou pedagógicas. De toda forma, foi possível observar que todas as escolas convergem na utilização de poucos e restritos mecanismos de trabalho, visto que o cenário acriano de apoio técnico e pedagógico por parte da Secretaria de Estado de Educação e Esporte ao que parece não consegue 
dar conta das necessidades da Rede Pública, composta por escolas de Regionais bastante diferentes entre si.

Quadro 2. Como as escolas vêm trabalhando a temática, segundo os coordenadores entrevistados

\begin{tabular}{|c|c|}
\hline Escolas & $\begin{array}{l}\text { Breves considerações acerca de como a escola vem trabalhando sobre gênero e } \\
\text { diversidade }^{5}\end{array}$ \\
\hline $\begin{array}{l}\text { Escola da } \\
\text { Regional } 1\end{array}$ & "Dentro de outros conteúdos como Sociologia e Filosofia." \\
\hline $\begin{array}{l}\text { Escola da } \\
\text { Regional } 2\end{array}$ & $\begin{array}{l}\text { "Estamos sempre abertos a discutir essa temática, bem como envolver membros da } \\
\text { comunidade que possivelmente se sintam incomodados com isso." }\end{array}$ \\
\hline $\begin{array}{l}\text { Escola da } \\
\text { Regional } 3\end{array}$ & $\begin{array}{c}\text { "A escola faz um trabalho interdisciplinar (Filosofia/Sociologia/Artes), através de } \\
\text { conversas, performances e clubes. Partimos do princípio de que "cidadania" não tem } \\
\text { cor, sexo, raça, etc." }\end{array}$ \\
\hline $\begin{array}{l}\text { Escola da } \\
\text { Regional } 4\end{array}$ & $\begin{array}{l}\text { "Recomenda-se a discussão da temática sempre que há oportunidade, buscando } \\
\text { inserir no contexto educacional o respeito à diversidade, não apenas nas questões de } \\
\text { gênero, mas m todos os aspectos da vida em sociedade." }\end{array}$ \\
\hline $\begin{array}{l}\text { Escola da } \\
\text { Regional } 5\end{array}$ & $\begin{array}{c}\text { Coordenador } 1 \text { - "Minha coordenação não se envolve com essa temática" } \\
\text { Coordenador } 2 \text { - "Conscientizando os professores sobre a implementação da } \\
\text { legis lação vigente." }\end{array}$ \\
\hline $\begin{array}{l}\text { Escola da } \\
\text { Regional } 6 \\
\end{array}$ & $\begin{array}{c}\text { "Trabalhamos pouco, pois não existem muitos projetos acessíveis e recursos que } \\
\text { venham da SEE." }\end{array}$ \\
\hline $\begin{array}{l}\text { Escola da } \\
\text { Regional } 7\end{array}$ & "Através de projetos de ciências que os professores da área elaboram" \\
\hline $\begin{array}{l}\text { Escola da } \\
\text { Regional } 8 \\
\end{array}$ & "Não há atividades específicas sobre a temática." \\
\hline $\begin{array}{l}\text { Escola da } \\
\text { Regional } 9\end{array}$ & $\begin{array}{l}\text { "A escola consegue fazer somente o básico, pois não há muito incentivo por parte da } \\
\text { Secretaria de Educação, e também não há abertura da sociedade para esse diálogo." }\end{array}$ \\
\hline
\end{tabular}

Fonte: Elaborado pelos autores, com dados coletados através de pesquisa empírica nas escolas.

Em relação ao seu próprio papel enquanto coordenadores(as) pedagógicos(as) e/ou de ensino, também foi solicitado que fizessem uma breve avaliação do trabalho e de seus eventuais esforços individuais no sentido de implementar atividades sobre gênero e diversidade na escola, abordando suas contribuições e atividades práticas.

\footnotetext{
${ }^{5}$ Considerações transcritas das respostas reais dadas pelos(as) coordenadores(as) entrevistados(as).
} 
Quadro 3. Considerações sobre suas próprias contribuições enquanto coordenadores de escolas da Rede

\begin{tabular}{|c|c|}
\hline Escolas & $\begin{array}{c}\text { Breves considerações acerca de suas próprias contribuições à frente das } \\
\text { coordenações pedagógicas e/ou de ensino das escolas de Ensino Médio } \\
\text { pesquisadas }^{6}\end{array}$ \\
\hline $\begin{array}{l}\text { Escola da } \\
\text { Regional } 1\end{array}$ & $\begin{array}{c}\text { "Estimulando o trabalho com os temas: intolerância, respeito às diferenças, e } \\
\text { atividades envolvendo as questões de gênero." }\end{array}$ \\
\hline $\begin{array}{l}\text { Escola da } \\
\text { Regional } 2\end{array}$ & $\begin{array}{c}\text { "Minha contribuição enquanto coordenadora é de promover e/ou incentivar debates } \\
\text { quando há a necessidade ou oportunidade." }\end{array}$ \\
\hline $\begin{array}{c}\text { Escola da } \\
\text { Regional } 3\end{array}$ & "Apenas consolidando um dos eixos dos valores definidos pela escola: respeito." \\
\hline $\begin{array}{l}\text { Escola da } \\
\text { Regional } 4\end{array}$ & $\begin{array}{l}\text { "A contribuição da coordenação se efetiva na medida em que se abre um espaço de } \\
\text { diálogo no ambiente escolar, buscando sempre priorizar o respeito às diferenças." }\end{array}$ \\
\hline $\begin{array}{l}\text { Escola da } \\
\text { Regional } 5\end{array}$ & $\begin{array}{l}\text { Coordenador } 1 \text { - "Não há contribuição de minha parte." } \\
\text { Coordenador } 2 \text { - Respondeu "Sim" sem desenvolver nenhuma ideia. }\end{array}$ \\
\hline $\begin{array}{l}\text { Escola da } \\
\text { Regional } 6\end{array}$ & $\begin{array}{l}\text { "O que eu posso fazer, faço, que é dialogar interdisciplinarmente com os alunos } \\
\text { sobre respeito à comunid ade LGBT. Mas é verdade, assim como provavelmente } \\
\text { muitos outros professores, acho que poderia fazer muito mais se houvesse apoio do } \\
\text { governo e da SEE." }\end{array}$ \\
\hline $\begin{array}{l}\text { Escola da } \\
\text { Regional } 7\end{array}$ & $\begin{array}{l}\text { "De maneira limitada, pois precisamos seguir as orientações curriculares, e não há } \\
\text { muito espaço para assuntos paralelos. Então quando os professores trabalham o corpo } \\
\text { humano, por exemplo, aproveitam para ensinar sobre sexualidade." }\end{array}$ \\
\hline $\begin{array}{l}\text { Escola da } \\
\text { Regional } 8\end{array}$ & 'o há atividades específicas sobre a temática." \\
\hline $\begin{array}{l}\text { Escola da } \\
\text { Regional } 9\end{array}$ & $\begin{array}{l}\text { "Sinceramente minha atuação é pouca, pois não fui formada para isso, e não vejo } \\
\text { muito incentivo da Secretaria para ajudar os professores." }\end{array}$ \\
\hline
\end{tabular}

Fonte: Elaborado pelos autores, com dados coletados através de pesquisa empírica nas escolas.

Por fim, quando questionados se acham que existem resistências políticas dentro da própria SEE, ou órgãos educacionais consultivos e deliberativos acrianos, em relação à inclusão desses temas nas escolas, 7 (sete) coordenadores(as) afirmaram que não, ao passo em que 3 (três) acham que sim - não obstante o fato de que esses 3 coordenadores comentaram sobre tais resistências no contexto político institucionalizado e social, o que de fato não caracteriza uma oposição que parte de dentro da SEE ou de órgãos educacionais consultivos e deliberativos.

\footnotetext{
${ }^{6}$ Considerações transcritas das respostas reais dadas pelos(as) coordenadores(as) entrevistados(as).
} 
Gráfico 13. Proporção de coordenadores entrevistados quanto a suas opiniões sobre a existência de resistências dentro da SEE ou de outros órgãos

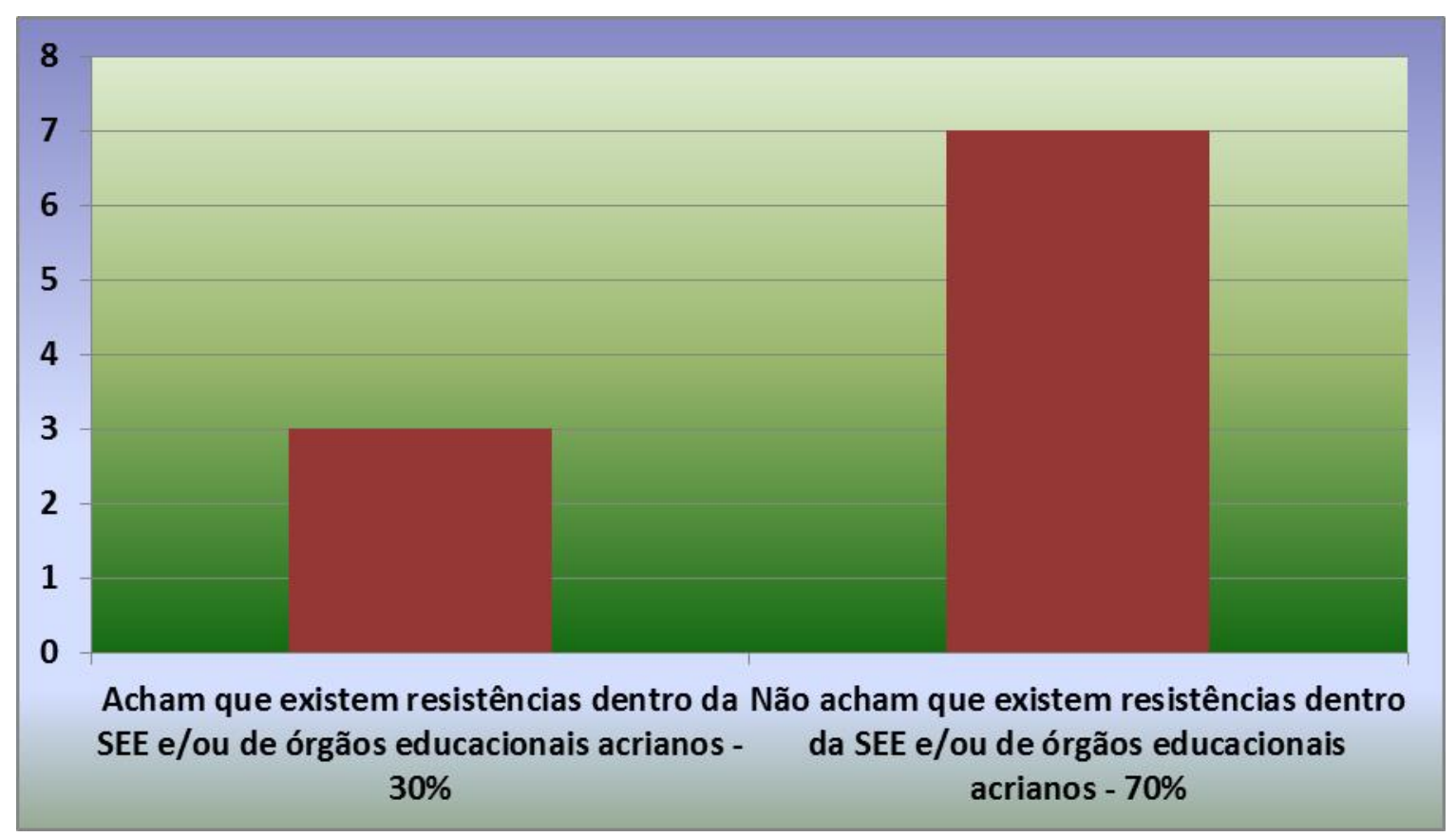

Fonte: Elaborado pelos autores, com dados coletados através de pesquisa empírica nas escolas.

Indubitavelmente, tais resultados apresentaram importantes implicações, todavia, de nenhuma forma as decorrências se esgotam com este trabalho acadêmico. Inicialmente, no estudo dos significados culturais sobre as questões de gênero e sexualidade, é fundamental que outros pesquisadores analisem as formas como tais significados se articulam em sistemas mais amplos de significação, historicamente construídos. Para isso, é essencial a realização de diálogos interdisciplinares para que sejam levantadas novas zonas de intersecção sobre fenômenos investigados. No caso das pesquisas sobre sexualidade, a análise das respostas dadas pelos sujeitos desta pesquisa evidenciou a importância de integrar um olhar atento sobre as questões de gênero, pois, segundo Muniz e Silva (2007), as formas como homens e mulheres vivenciam e dão significado à sua sexualidade é mediada, de forma intensa, pelo sistema de crenças, valores e práticas sociais encaminhadas pelas questões de gênero.

\section{CONSIDERAÇÕES FINAIS}

A trajetória percorrida neste trabalho teve como objeto a análise da importância do diálogo sobre liberdade de gênero e diversidade sexual na educação escolar, considerando principalmente o âmbito regional e local, no contexto da Rede Estadual de Educação Básica do Acre. Nesse contexto, foi necessária uma observação crítica da temática de modo a identificar se de fato a Rede acriana tem um trabalho estruturado de ações sobre diversidade e se tais eventuais atividades refletem demandas sociais e educacionais de combate a preconceitos no cenário do Estado do Acre. 
Por intermédio dessa pesquisa foi possível identificar que existe um razoável conhecimento sobre a importância de se tratar diversidade na escola, por parte dos gestores da Rede e coordenadores das escolas de Ensino Médio que representaram a Rede Pública Estadual. Entretanto, ficou evidente, de toda forma, a escassez de mecanismos institucionais e educacionais planejados para uma efetiva ação escolar no contexto das comunidades. Há se de perceber que os docentes, atores diretos na construção da rotina escolar, não conseguem dar conta de dialogar sobre liberdade de gênero e diversidade sexual num cenário de pouco incentivo e falta de elementos curriculares e pedagógicos.

Trabalhar com diversidade não é, portanto, ignorar as diferenças ou impedir o exercício da individualidade. [...] É preciso dar espaço para a expressão de cada um e para a participação de todos na construção de um coletivo apoiado no conhecimento mútuo, na cooperação e na solidariedade. (AMBROSETTI, 1999, p. 92).

No que tange ao observado na Rede, quando da visita e aplicação dos questionários semiabertos, foi possível perceber a grande demanda de trabalho que absorve a rotina dos professores das escolas que, muitas vezes, acumulam funções que extrapolam suas atividades docentes. Nesse contexto, devem ser consideradas as responsabilidades atribuídas aos docentes e coordenadores, no sentido que explicar os altos índices de obsolência das escolas, que pouco fazem para efetivar um diálogo sobre diversidade. Em todo caso, tal acúmulo de trabalho que emerge das dificuldades educacionais não justifica por completo os níveis de escassez de atividades curriculares sobre diversidade e multiculturalismo, visto que na democracia é fundamental que haja diálogo como ponto de partida para quaisquer tomadas de decisões políticas.

A partir do observado na análise dos dados obtidos, conclui-se que a Rede Pública de Educação Básica do Acre, não obstante a falta de mecanismos institucionais para inserção dos temas em voga nos currículos escolares, possui experiências de diálogo que tentam timidamente contextualizar as questões de diversidade, no que tange à explanação sobre respeito mútuo nas relações sociais. De toda forma, vê-se que tal forma de trabalhar tais questões não dá conta de contextualizar a trajetória social de conflitos que surgem a partir do preconceito historicamente vinculado às comunidades LGBTQIA. Para além disso, sob a luz de experiências comparadas, metodologias tímidas sobre questões de liberdade de gênero e diversidade sexual não são capazes de propor mudanças efetivas nas estruturas do imaginário social. Dessa forma, é necessário que o Estado através das Redes Públicas de Ensino compreenda a importância do tratamento interdisciplinar de tais questões, de forma a trabalhar a cidadania envolvendo todos os condicionantes sociais, históricos e psicológicos. 
Em relação à visão de gestores e coordenadores da Rede Estadual de Educação Básica do Acre sobre as questões relacionadas à liberdade de gênero e diversidade sexual em âmbito escolar, pode-se observar que parcela considerável do universo investigado já lidou em sala de aula ou no ambiente escolar com questões relacionadas a sexo e/ou orientações sexuais, de forma que a grande maioria acha importante a inclusão de tais discussões nas atividades escolares cotidianas. Entretanto, sob o viés de uma sociedade contemporânea fincada em um discurso conservador que não compreende bem as relações pós-modernas de hibridismo e multiculturalismo, percebe-se também no contexto dessa pesquisa a tendência da Rede em tratar timidamente das questões de gênero e diversidade, sob pontos de vista científicos e biológicos, em detrimento de discussões antropológicas e sociais mais profundas.

Destarte, a fim de conseguir responder todos os questionamentos desta pesquisa à luz da abordagem da metodologia, foi possível identificar quais os maiores obstáculos para se trabalhar a questão do gênero e da diversidade sexual nas escolas acrianas, sob o viés do olhar de gestores e coordenadores da Rede Pública Estadual. No que se refere à resistência de grupos da sociedade que não gostariam que esse tema fosse discutido na escola viu-se que, na opinião dos sujeitos entrevistados, grupos ligados principalmente a contextos religiosos, tendem a dificultar a sistematização pedagógica de atividades sobre gênero e diversidade, o que sob o ponto de vista histórico, coloca obstáculos à liberdade institucional que a escola deveria possuir no contexto de uma sociedade diversa e plural.

Assim, conclui-se que a Rede Estadual de Educação Básica do Acre trabalha pouco com questões relacionadas à liberdade de gênero e diversidade sexual em seu contexto educacional, apesar de existir um arcabouço de documentos normativos com capacidade de guiar a construção de sistemas estruturados de diálogo e amenizar os preconceitos a partir da escola. Nesse contexto, a análise de como as políticas públicas educacionais em curso na Rede de Educação do Acre trabalham com as questões relacionadas à liberdade de gênero e diversidade sexual, cujo cerne baseou o objetivo geral dessa pesquisa, afluiu em um cenário aparentemente desanimador, mas eventualmente acessível a políticas governamentais que proponham mudanças curriculares e pedagógicas de inserção efetiva do tema na educação. Foi possível observar que a Rede não é obrigada coercitivamente a seguir tais regras de conduta conservadora, mas vai sutilmente acatando as imposições difundidas por discursos tradicionais e tecnocráticos de cunho governamental e político - nesse quesito mora a importância da linguagem enquanto elemento central da difusão lenta, mas gradual, de normas preconceituosas e estereotipadas. 
Diante disso, ao se tratar sobre o que de fato é realizado em matéria de gênero e diversidade na Rede Pública de Educação do Acre, sempre caberá, independente da época de análise, um olhar atento sobre as inúmeras vozes que fazem parte do campo educacional contextualizado, para que seja possível a compreensão holista de como se formam os sujeitos e as subjetividades nele presentes.

Uma política educacional que queira recuperar essas culturas negadas não pode ficar reduzida a uma série de lições isoladas. [...] É necessário um currículo que em todos os dias do ano letivo, em todas as tarefas acadêmicas e em todos os recursos didáticos estejam presentes as culturas silenciadas. (SANTOMÉ, 1995, p. 67).

No contexto da relação entre gênero e escola, a instituição escolar tem uma dupla função, qual seja a formação intelectual e o desenvolvimento social dos indivíduos. Nesse sentindo, seria importante que a escola ultrapassasse a sistemática institucional tradicional observada no contexto da Rede acriana, questionando e incitando a comunidade a organizar novas formas de interpretar o mundo.

Por fim, não propomos, no corpo desse artigo de estudo teórico, respostas para todas as questões levantadas. O que se busca é lançar alternativas de reflexão sobre liberdade de gênero e diversidade sexual no contexto das políticas públicas educacionais da Rede Pública de Educação Básica do Acre, de forma que o leitor possa elaborar diferentes maneiras de enxergar a construção de muitos preconceitos presentes na sociedade acriana. $O$ que se indica são mudanças na esteira de um permanente projeto de desenvolvimento social e educacional que se preocupe, de fato, com o futuro da educação deste país. 


\section{REFERÊNCIAS}

AMBROSETTI, Neusa Banhara. O "Eu” e o "Nós": trabalhando com a diversidade em sala de aula. São Paulo: Papirus, 1999.

INSTITUTO BRASILEIRO DE CIÊNCIAS CRIMINAIS. Boletim 149. São Paulo: 2005. Disponível em: <https:// www.ibccrim.org.br/boletim_artigo/2950-Diferencas-de-genero-liberdade-e-igualdade>. Acesso em: 26 nov. 2017.

LIMA, Rita L. Identidade, diversidade de gênero e religião: algumas reflexões. Rio de Janeiro: Em Pauta, 2011.

LOPES, Lourival da Silva. Os saberes da experiência do professor e suas implicações na prática pedagógica. Porto: AFIRSE, 2009.

MUNIZ, Alexsandro Dias; SILVA, Daniela Regina da. Sexualidade e gênero. Florianópolis: UNIASSELVI, 2007.

SANTOMÉ, Jurjo Torres. As culturas negadas e silenciadas no Currículo. In: SILVA, Tomaz Tadeu. (Org.). Alienígenas na sala de aula - Uma introdução aos estudos culturais em educação. Petrópolis: Vozes, 1995.

VIANNA, Cláudia Pereira. A feminização do magistério na educação básica e os desafios para a prática e a identidade coletiva docente. In: YANNOULAS, Silvia Cristina. (Org.). Trabalhadoras: análise da feminização das profissões e ocupações. Brasília, DF: Abaré, 2013.

\section{RESUMO}

O artigo apresenta discussões relativas à liberdade de gênero e a diversidade sexual no contexto das políticas educacionais, tendo como campo empírico a Rede Pública de Educação Básica do Estado do Acre. Realizaramse visitas à Secretaria de Estado de Educação e Esporte e a nove escolas de Ensino Médio, representando todas as regionais escolares que compõem a Rede, onde foram aplicadas entrevistas semiabertas junto aos sujeitos que compõem a gestão estadual e as coordenações pedagógicas e de ensino das referidas escolas, com o objetivo de conhecer e analisar a realidade, no contexto educacional acriano, do diálogo existente sobre liberdade de gênero e diversidade sexual. Os aspectos conclusivos da pesquisa apontam que a Rede Pública de Educação Básica não se opõe à discussão acerca da inclusão do tema liberdade de gênero e diversidade sexual em seus currículos, apesar da inegável resistência paralela que há por parte de alguns setores conservadores da sociedade. Todavia faltam mecanismos legais, técnicos e principalmente pedagógicos que possibilitem a consolidação de políticas educacionais igualitárias e que combatam todo e qualquer dispositivo institucional e social de conservação de preconceitos historicamente construídos.

Palavras-chave: Liberdade de Gênero. Diversidade Sexual. Rede Pública de Educação Básica do Acre.

\section{SEXUAL AND GENDER FREEDOM IN THE ACRE EDUCATION NETWORK: OBSERVING THE LOCAL CONTEXT}

\section{ABSTRACT}

The article presents discussions about gender freedom and sexual diversity in the context of educational policies, having as empirical field the Public Basic Education Network of the State of Acre. Visits were made to the State Department of Education and Sports and to nine high schools, representing all the regional schools that make up the Network, where semi-open interviews were applied to the subjects that make up the state administration and pedagogical and teaching coordinations of these schools, with the objective of knowing and analyzing the reality, in the acriano educational context, of the existing dialogue on freedom of gender and sexual diversity. The conclusive aspects of the research indicate that the Public Basic Education Network does not oppose the discussion about the inclusion of the topic of gender freedom and sexual diversity in its curricula, despite the undeniable parallel resistance that exists on the part of some conservative sectors of society. However, there is a lack of legal, technical, and especially pedagogical mechanisms that allow the consolidation of egalitarian educational policies and combat any and all institutional and social mechanisms for preserving historically constructed prejudices.

Keywords: Freedom of gender. Sexual diversity. Public Network of Basic Education of Acre. 


\section{LIBERTAD SEXUAL Y DE GÉNERO EN LA RED DE EDUCACIÓN DEL ACRE: OBSERVANDO EL CONTEXTO LOCAL}

\section{RESUMEN}

El artículo presenta discusiones relativas a la libertad de género y la diversidad sexual en el contexto de las políticas educativas, teniendo como campo empírico la Red Pública de Educación Básica del Estado de Acre. Se realizaron visitas a laSecretaría de Estado de Educación y Deporte yanueveescuelas de Enseñanza Media, representando a todas las regionales escolares que componen la Red, donde se aplicaron entrevistas semiabiertas junto a los sujetos que componen la gestión estadual y las coordinaciones pedagógicas y de enseñanza de las referidas escuelas, con el objetivo de conocer y analizar la realidad, en el contexto educativo acriano, del diálogo existente sobre libertad de género y diversidad sexual. Los aspectos concluyentes de lainvestigaciónapuntan que la Red Pública de Educación Básica no se opone a la discusión sobre la inclusión del tema de libertad de género y diversidad sexual en sus currículos, a pesar de la innegableresistencia paralela que hay por parte de algunos sectores conservadores de la sociedad. Sin embargo, faltan mecanismos legales, técnicos y principalmente pedagógicos que posibilitenlaconsolidación de políticas educativas igualitarias y que combatan todo y cualquier dispositivo institucional y social de conservación de preconceptoshistóricamenteconstruidos.

Palabras clave: Libertad de género. Diversidad sexual. Red Pública de Educación Básica de Acre.

Submetido em: 20 de novembro de 2018 Aprovado em: 20 de maio de 2019 